\title{
Work-Life Balance and Job Satisfaction among Worker Women
}

\author{
Ghina Rona Thifal ${ }^{1}$, Fitri Ayu Kusumaningrum ${ }^{2}$ \\ \{fitriayukusumaningrum@uii.ac.id²\} \\ Department of Psychology, Universitas Islam Indonesia, Indonesia ${ }^{1,2}$
}

\begin{abstract}
The purpose of this study was to analyze the relationship between balance of work and employment among working women. The study participants included 134 women from X and Y companies in Yogyakarta, Indonesia. The hypothesis proposed was that the balance between work and life and satisfaction among respondents was positive and significant. The study used the Job Satisfaction Survey (Cronbarch's Alpha $=0.930$ ), and the Work-Life Balance Scale (Cronbachs Alpha $=0.795)$ to measure the work-life balance. Analysis of the data using a rho correlation technique by Spearman showed that in working women there was a strong and positive relationship between work-life balance and employment satisfaction $(r=0.352, \mathrm{p}<0.000)$. The result implied the higher the balance between work and life of the respondents, the higher the level of satisfaction at work and vice versa. In addition, the results also showed that the job-life balance variable affected 12.39 percent job satisfaction.
\end{abstract}

Keywords: Work-life balance, job satisfaction, worker women

\section{Introduction}

Today working women were no longer considered taboo. Women in the near past were limited to the domestic sector activities. Nowadays this limitation was no longer standing as women could be seen working in many public sectors even became leaders in such services [1], [2]. The percentage of working women increased compared to previous years including in Indonesia where the total female worker participation was $55.44 \%$ [3]. Several factors influenced women to work, including economic and social factors [4]. The economic factor was the willingness to improve family welfare, while the social factor was the element of prestige, especially for women who were highly educated and thought that work was self-actualization. Therefore, many married women agreed that working outside the home had a high value, even though the expected wages were not what they wanted.

The results of another survey conducted by CNN Indonesia in 2016 showed that as many as 77 percent of employees claimed to be dissatisfied with the allowances and facilities provided by the company [5], 83 percent of correspondents felt that the company did not give appreciation for employee performance. The results of another survey conducted by the Global Leadership Study in 2018 showed 83 percent of employees in Indonesia said they were not satisfied with their work [6]. This research shows that satisfaction is most strongly influenced by the behavior of the boss.

Workers had various values toward works which affected their job satisfaction [7]. Previous research emphasized the role of job characteristics as determinants of job satisfaction [8] as well 
as organizational determinants such as leadership [9]. To achieve job satisfaction, workers needed the opportunity to utilize various technique in the job so that their responsibilities could be handled properly [7].

Dissatisfied employees could leave the job, often complain, disobey, steal company goods, avoid job responsibilities [10]- [12]. Job satisfaction is very important because employees were the most dominant factor in determining the success or failure of activities in an organization [13], [14] and were the biggest resource of any organization [15]. Employment satisfaction has created innovative ideas amongst employees that enable people to become loyal to the organization. Workers would be more satisfied if the efficient work-life balance and stress management policies would be what they expect.

Spector [16] argued that job satisfaction included an employee's feelings in general about the work or as an interconnected series of employee's attitudes towards aspects of the work. If the company could influence the job satisfaction of employees, it would get many benefits. The benefits of employee job satisfaction included the work being completed faster, damage can be reduced, absenteeism, employee turnover and unit costs can be reduced, and work productivity can be increased [17]. The characteristics of satisfied workers were having high motivation to work and are happier to do their jobs, while the characteristics of workers who are less satisfied are feeling lazy to go to work and not enthusiastic about doing their work [18], [19].

The low job satisfaction of women according to Spector [16] could cause employee health to decline both physically and mentally. Another impact was the stress at work, which demonstrated an important negative relationship between work stress and job satisfaction [20]. The higher the level of stress at work, the lower the satisfaction at work. The job satisfaction also had a significant negative connection with the intention of turnover [21]. It meant that the higher the intention to sell the lower the job satisfaction.

Job satisfaction could be influenced by several factors including psychological, social, physical and financial ones [22], [23]. The survey results from Jobstreet.com in 2014 showed that $73 \%$ of employees were dissatisfied with their jobs. This is due to several factors, including work not according to educational background, no career path, military superior / paternalist / indifferent character and not having a work-life balance or balance between life and work. The factor that has the most influence is not having a work-life balance. As many as $85 \%$ of correspondents admit that they do not have a balance between work and personal life. In this research, one of the factors to be examined in relation to job satisfaction is work-life balance $[5]$.

The presence of work-life balance would increase job satisfaction or at least it could help generating a job satisfaction. Previous research explained that employees would feel satisfied with work and family life if there was a positive response in their work environment [24], [25]. Another research also showed a positive and significant relationship between work life balance and job satisfaction among pharmacy company employees. The work life balance variable affected employee job satisfaction by $42.2 \%$ and the rest was influenced by other variables [26]. Other research showed that work-life balance had a significant positive effect on job satisfaction for female employees in commercial banks [27].

Work-life balance was a form of individual satisfaction in achieving a balance of life and work [26], [28]. When work interfered with personal life, it would disturb the work-life balance of employees [29]. Individual behavior could be a source of conflict and a source of energy for individuals. If individuals could carry out responsibilities in work and personal life simultaneously, they would feel job satisfaction because the work could be done well in the office without being disturbed by personal or family problems [30]. 
The women joining the workforce had many consequences, especially for those with family members. Women involving in the workforce had double burden. They were required to be committed to their work, while at the same time they should also give priority to the role in the family as housewives [31]. Having a dual role both as a worker and as a housewife can make women unbalanced and there is a clash between worker responsibilities and the homewife responsibility. Both roles require an equally good performance and can sacrifice a lot for their families if women give priority to work.

Therefore, a combination of family and organizational support would certainly be better at reducing the existing clash of responsibility. Personal and organizational supports were very influential on workers in resolving conflicts of interest between work and personal life. There was a very significant difference between workers who are supported by their families and workers who are not supported by their families [32], [33].

Several studies with a similar concept of job satisfaction and work-life balance on female workers had been investigated by many researchers. Research on relationship among female doctor respondents found a significant positive result [34]. The results with significant relationship were also found among women teachers [35], Banking and education women[36] as well as building industry women[37],[38]. This paper examines in greater detail the relationship between work life balance and satisfaction for working women, based on the description above and previous research.

\section{Method}

Respondents in this study were women who worked in companies in Yogyakarta. The total number of subjects in this study were 134 people. Respondents who are deemed to have met the subject's criteria are women who work in a company and are over 17 years old.

The job satisfaction scale used was the Job Satisfaction Survey which was adapted from Spector [39]. This scale can measure 9 aspects of job satisfaction, namely aspects of salary, aspects of promotion, aspects of superiors, aspects of additional benefits, aspects of rewards, aspects of work regulations and procedures, aspects of coworkers, aspects of job appraisal itself and aspects of communication.

The scale of this study is an adjusted Fisher, Bulger and Smith work-life balance [29]. The scale comprises 17 items with 6 favorite items and 11 unfavorable items. This measuring tool measures four dimensions of the work-life balance: work interferes with the lives of people (WIPL), work interferes with the work of people (PLIW), work is improved with life (WEPL) and personal life improves with work (PLEW). The model used in the balance of work-life is the Likert scale.

The results of the reliability test of the job satisfaction scale showed a Cronbach's alpha $(\alpha)$ reliability score of 0.930 with a validity score that moved from -0.252 to 0.797 . The results of the work-life balance scale reliability test showed a Cronbach's alpha $(\alpha)$ reliability score of 0.795 with a validity score that moved from 0.067 to 0.666 .

Hypothesis testing is used to test the validity of a statement statistically. The purpose of hypothesis testing is to establish a basis for determining the decision to reject or accept the truth of the assumptions made. Hypothesis testing is done using Spearman's rho correlational technique when the data are abnormal, while for normal data using Pearson's correlational technique. The hypothesis is accepted if it has a significance coefficient value of $\mathrm{p}<0.01$. 


\section{Results and Discussion}

\subsection{Results}

Normality test using Kolmogorov-Smirnov Test indicated that both job satisfaction and work-life balance had significance value $\mathrm{p}=0.200(\mathrm{p}<0.05)$. Thus, both variables were normally distributed. Linearity test result showed that job satisfaction and work-life balance had linearity coefficient $F=19.784$ and significance coefficient $p=0.000(p<0.05)$. This result showed a linear correlation between job satisfaction and work-life balance. The test hypothesis using rho correlation technique from Spearman indicated correlation coefficient $r=0.352$, meaningful coefficient $\mathrm{p}=0.000$ and coefficient $\mathrm{r} 2=0.123$. These results indicated that the relationship between satisfaction at work and balance between work-life in working women was significantly positive. The hypothesis proposed in this study has therefore been accepted. The results also revealed that the effective contribution of work-life balance to job satisfaction was 12.3 percent. This indicated that other factors, about 87.7 percent, contributed to the satisfaction of the study's respondents.

Further analysis was carried out to analyze the correlation between work-life balance aspects and work satisfaction. The results of this test were summarized in Table 1. There have been three considerable and positive correlations with job satisfaction in the work-life balance. Interference in personal life, interference in work and work. The improvement of personal life showed significant correlation between $\mathrm{r}=0.317, \mathrm{r}=0.162$ and $\mathrm{r}=0.321$ with respect.

Table 1. Results of correlation test between aspects of work-life balance and job satisfaction

\begin{tabular}{llll}
\hline \multicolumn{1}{c}{ Variable } & $r$ & $p$ & $r^{2}$ \\
\hline Work Interference with Personal Life and Job Satisfaction & 0.317 & 0.00 & 0.10 \\
Personal Life Interference with Work and Job Satisfaction & 0.162 & 0.03 & 0.02 \\
Work Personal Life Enhancement and Job Satisfaction & 0.321 & 0.00 & 0.10 \\
\hline
\end{tabular}

\subsection{Discussions}

The purpose of this study was to analyze the relation among working women in Yogyakarta, Indonesia between work-life balance and job satisfaction. The study was conducted with 134 participants. The statistical analysis showed that the distribution of data was normal and that the data was either linear or not straight. The hypothesis in this study was that the relation between job satisfaction and balance between work and life was positive. Based on the results of Pearson correlation testing, a positive relationship was found between work-life balance and job satisfaction.

Earlier studies have shown a good correlation between balance between work and life and job satisfaction [17], [40], [41]. This implied that the higher the balance between work and life, the higher the satisfaction of the worker. Conversely, the lower the balance between work and life, the lower the satisfaction of the respondents. It could therefore be concluded that the hypothesis was accepted in this study.

The results of further analysis on every aspect of the work/life balance showed a significant positive relationship. Work interference with personal life and work interference had a positive and important relation to job satisfaction. This contradicts previous findings showing that interference with personal life has a negative relation to job satisfaction [42]. This means that the greater the interference in the workplace, the greater the job satisfaction and vice versa. The 
improvement in personal life work had a positive and significant relationship to job satisfaction. This was in line with previous studies in Oman [42] and Philippines [35]. The higher the work personal life improvement, the greater the satisfaction of the job and vice versa.

The results also showed that aspects of work-life balance contribute effectively to job satisfaction. Work interference with personal life has contributed 10 percent effectively to the satisfaction of employment. Personal Life Interference with Work has contributed 2.6\% to job satisfaction. The improvement in personal life work has provided an effective contribution of 10.3 percent.

\section{Conclusion}

This study showed that the balance of work-life and job satisfaction among working women in companies $\mathrm{X}$ and $\mathrm{Y}$ in Yogyakarta, Indonesia was a positive and significant relationship. This meant that the greater the balance between work and life among the respondents, the higher the job satisfaction and vice versa. The limitation of this research was limited problems explored in the research area. Furthermore, distribution of the questionnaire was directly because of the work load of the respondents. The questionnaire was entrusted to the human resource departments of the company in each office. It implied that the researchers could not ensure that all respondents fill out the questionnaire properly and according to their circumstances without bias.

\section{Acknowledgements}

The authors thank Department of Psychology, Universitas Islam Indonesia, Indonesia for providing required resources in this study. The authors solely bare the responsibility for the findings of the study.

\section{References}

[1] S. M. Neuse, "Professionalism and authority: Women in public service," Public Adm. Rev., vol. 38, no. 5, pp. 436-441, 1978, doi: 10.2307/975502.

[2] A. E. Smith, "On the edge of a glass cliff: Women in leadership in public organizations," Public Adm. Q., vol. 39, no. 3, pp. 484-517, 2015, [Online]. Available: https://www.jstor.org/stable/24773425.

[3] Badan Pusat Statistik, "Keadaan Ketenagakerjaan Indonesia Agustus 2020," Jakarta, 2020.

[4] N. M. Putri and E. Y. Purwanti, "Analisis penawaran tenaga kerja wanita menikah dan faktor yang mempengaruhinya di Kabupaten Brebes," Diponegoro J. Econ., vol. 1, no. 1, pp. 1-13, 2012, [Online]. Available: https://ejournal3.undip.ac.id/index.php/jme/article/view/317.

[5] E. Priherdityo, "Survei: 77 persen karyawan tidak puas tunjangan kerja," CNN Indonesia, 2016.

[6] F. M. Sari, "Terkuak, 30 persen karyawan RI ingin pindah kerja," Liputan6, 2018.

[7] A. L. Kalleberg, "Work values and job rewards: A theory of job satisfaction," Am. Sociol. Rev., vol. 42, no. 1, pp. 124-143, 1977, doi: 10.2307/2117735.

[8] C. Glisson and M. Durick, "Predictors of job satisfaction and organizational commitment in human service organizations,” Adm. Sci. Q., vol. 33, no. 1, pp. 61-81, 1988, doi: 10.2307/2392855. 
[9] T. S. Bateman and S. Strasser, "A longitudinal analysis of the antecedents of organizational commitment," Acad. Manag. J., vol. 27, no. 1, pp. 95-112, 1984, doi: 10.2307/255959.

[10] J. P. Boichuk and B. Menguc, "Engaging dissatisfied retail employees to voice promotive ideas: the role of continuance commitment," J. Retail., vol. 89, no. 2, pp. 207-218, 2013, doi: https://doi.org/10.1016/j.jretai.2013.01.001.

[11] D. E. Bowen, "Some unintended consequences of intention to quit," Acad. Manag. Rev., vol. 7, no. 2, pp. 205-211, 1982, doi: 10.2307/257298.

[12] S. Fernandez and T. Moldogaziev, "Employee empowerment, employee attitudes, and performance: Testing a causal model,” Public Adm. Rev., vol. 73, no. 3, pp. 490-506, 2013, [Online]. Available: http://www.jstor.org/stable/42002955.

[13] M. Patterson, P. Warr, and M. West, "Organizational climate and company productivity: The role of employee affect and employee level," J. Occup. Organ. Psychol., vol. 77, no. 2, pp. 193-216, Jun. 2004, doi: 10.1348/096317904774202144.

[14] M. Hitka, Z. Závadská, D. Jelačić, and Ž. Balážová, "Qualitative indicators of company employee satisfaction and their development in a particular period of time," Drv. Ind., vol. 66, no. 3, pp. 235239, 2015, doi: 10.5552/drind.2015.1420.

[15] R. K. Yadav and N. Dabhade, "Work life balance and job satisfaction among the working women of banking and education sector - A comparative study,” Int. Lett. Soc. Humanist. Sci., vol. 21, pp. 181-201, 2014, doi: 10.18052/www.scipress.com/ILSHS.21.181.

[16] P. E. Spector, Job satisfaction: Application, assesment, causes, and consuquences. Thousand Oaks, California: SAGE Publications Inc., 1997.

[17] M. W. Wenno, "Hubungan antara work-life balance dan kepuasan kerja pada karyawan di PT PLN Persero Area Ambon,” J. Maneksi, vol. 7, no. 1, pp. 47-54, 2018, doi: 10.31959/jm.v7i1.86.

[18] R. E. Smerek and M. Peterson, "Examining Herzberg's Theory: Improving Job Satisfaction among Non-academic Employees at a University,” Res. High. Educ., vol. 48, no. 2, pp. 229-250, 2007, doi: 10.1007/s11162-006-9042-3.

[19] E. A. Maidani, "Comparative Study of Herzberg's Two-Factor Theory of Job Satisfaction among Public and Private Sectors," Public Pers. Manage., vol. 20, no. 4, pp. 441-448, Dec. 1991, doi: $10.1177 / 009102609102000405$.

[20] M. Vasan, "Impact of job stress and job satisfaction among pharmaceutical sales representatives," Res. J. Pharm. Technol., vol. 11, no. 9, pp. 3759-3764, 2018, doi: 10.5958/0974360X.2018.00688.1.

[21] A. Alam and M. Asim, "Relationship between job satisfaction and turnover intention," Int. J. Hum. Resour. Stud., vol. 9, no. 2, pp. 163-194, 2019, doi: 10.5296/ijhrs.v9i2.14618.

[22] K. Rezaei, M. Omidi, and H. Kazeroni, "A study of constructive factors in job satisfaction," Eur. Online J. Nat. Soc. Sci., vol. 2, no. 3 Special Issue on Accounting and Management, pp. 3468-3477, 2013, [Online]. Available: http://european-science.com/eojnss/article/view/1597.

[23] N. Hashiguchi et al., "The Effects of Psychological Factors on Perceptions of Productivity in Construction Sites in Japan by Worker Age," International Journal of Environmental Research and Public Health, vol. 17, no. 10. 2020, doi: 10.3390/ijerph17103517.

[24] A. L. Saltzstein, Y. Ting, and G. H. Saltzstein, "Work-family balance and job satisfaction: The impact of family-friendly policies on attitudes of federal government employees," Public Adm. Rev., vol. 61, no. 4, pp. 452-467, Jul. 2001, doi: https://doi.org/10.1111/0033-3352.00049.

[25] R. W. Y. Yee, A. C. L. Yeung, and T. C. E. Cheng, "The impact of employee satisfaction on quality and profitability in high-contact service industries," J. Oper. Manag., vol. 26, no. 5, pp. 651-668, 2008, doi: https://doi.org/10.1016/j.jom.2008.01.001.

[26] I. M. D. Ganapathi, "Pengaruh work-life balance terhadap kepuasan kerja karyawan (Studi pada PT Bio Farma Persero)," J. Ecodemica, vol. 4, no. 1, pp. 125-135, 2016, doi: 10.31294/jeco.v4i1.354.

[27] W. O. Nurhasanah M, L. O. Kalimin, and D. T. Syaifuddin, "The effect of work-life balance on job satisfaction and female employee performance in commercial bank in Kendari City," IOSR J. Bus. Manag., vol. 21, no. 5 Ser. II, pp. 1-7, 2019, doi: 10.9790/487X-2105020107.

[28] D. Hutchinson, Lead with balance: How to master work-life balance in an imbalanced culture. Charleston, North Carolina: Advantage Media Group, 2016. 
[29] G. G. Fisher, C. A. Bulger, and C. S. Smith, "Beyond work and family: A measure of work/nonwork interference and enhancement," J. Occup. Health Psychol., vol. 14, no. 4, pp. 441-456, 2009, doi: $10.1037 / \mathrm{a} 0016737$.

[30] S. E. Anderson, B. S. Coffey, and R. T. Byerly, "Formal organizational initiatives and informal workplace practices: Links to work-family conflict and job-related outcomes," J. Manage., vol. 28, no. 6, pp. 787-810, Dec. 2002, doi: 10.1177/014920630202800605.

[31] L. Duxbury, M. Stevenson, and C. Higgins, "Too much to do, too little time: Role overload and stress in a multi-role environment," Int. J. Stress Manag., vol. 25, no. 3, pp. 250-266, 2018, doi: $10.1037 /$ str0000062.

[32] S. D. Friedman and J. H. Greenhaus, Work and family--allies or enemies?: What happens when business professionals confront life choices. Oxford: Oxford University Press, 2000.

[33] K. L. Evans, J. Millsteed, J. E. Richmond, M. Falkmer, T. Falkmer, and S. J. Girdler, "Working sandwich generation women utilize strategies within and between roles to achieve role balance," PLoS One, vol. 11, no. 6, 2016, doi: 10.1371/journal.pone.0157469.

[34] Anuradha and M. Pandey, "Impact of work-life balance on job satisfaction of women doctors," Probl. Perspect. Manag., vol. 14, no. 2-2, pp. 319-324, 2016, doi: 10.21511/ppm.14(2-2).2016.07.

[35] J. O. Mercado, "Work life balance and level of satisfaction among women teachers assigned in the northernmost part of the Province of Surigao Del Sur, Philippines," South East Asian J. Manag., vol. 13, no. 2, pp. 140-150, 2019, doi: 10.21002/seam.v13i2.11344.

[36] R. K. Yadav and S. S. Yadav, "Impact of work life balance and stress management on job satisfaction among the working women in public sector banks," Int. Lett. Soc. Humanist. Sci., vol. 26, pp. 63 70, 2014, doi: 10.18052/www.scipress.com/ILSHS.26.63.

[37] E. K. Malone and R. R. A. Issa, "Work-life balance and organizational commitment of women in the US construction industry," J. Prof. Issues Eng. Educ. Pract., vol. 139, no. 2, pp. 87-98, Apr. 2013, doi: 10.1061/(ASCE)EI.1943-5541.0000140.

[38] E. K. Malone and R. R. A. Issa, "Predictive models for work-life balance and organizational commitment of women in the US construction industry," J. Constr. Eng. Manag., vol. 140, no. 3, p. 4013064, Mar. 2014, doi: 10.1061/(ASCE)CO.1943-7862.0000809.

[39] P. E. Spector, "Measurement of human service staff satisfaction: Development of the Job Satisfaction Survey," Am. J. Community Psychol., vol. 13, no. 6, pp. 693-713, 1985, doi: 10.1007/BF00929796.

[40] E. Yusnani and A. P. Prasetio, "Kontribusi work life balance terhadap job satisfaction pada karyawan Dinas Koperasi dan Usaha Kecil,” J. Penelit. Pendidik., vol. 18, no. 2, pp. 135-143, 2018, [Online]. Available: https://ejournal.upi.edu/index.php/JER/article/view/12954.

[41] U. Y. Asepta and S. H. P. Maruno, "Analisis pengaruh work-life balance dan pengembangan karir terhadap kepuasan kerja karyawan PT. Telkomsel, Tbk Branch Malang," J. Ilm. Bisnis dan Ekon. Asia, vol. 11, no. 2, pp. 77-85, 2017, doi: 10.32812/jibeka.v11i2.64.

[42] K. Agha, F. T. Azmi, and A. Irfan, "Work-life balance and job satisfaction: An empirical study focusing on higher education teachers in Oman," Int. J. Soc. Sci. Humanit., vol. 7, no. 3, pp. 164171, 2017, doi: 10.18178/ijssh.2017.V7.813. 